\title{
Some Phrygian Plant and Insect Remains from Kerkenes Dağ, Central Anatolia (Turkey)
}

\author{
Alexia Smith ${ }^{1 *}$ and Scott Branting ${ }^{2}$ \\ Author address: ${ }^{1}$ University of Connecticut, Department of Anthropology, Beach Hall Room 406, U-1176, 354 Mansfield \\ Road, Storrs, Connecticut 06269-1176 USA, ${ }^{2}$ The Oriental Institute, Room 207, The University of Chicago, 1155 East $58^{\text {th }}$ \\ Street, Chicago, Illinois 60637 USA \\ ${ }^{*}$ Corresponding Author: alexia.smith@uconn.edu
}

Received: February 15, 2014

Volume 5:44-51

Published: April 30, 2014

(C) 2014 Society of Ethnobiology

\begin{abstract}
During the 1996 and 2000 seasons of excavation at Kerkenes Dağ, a large single-period Phrygian mountain-top city located in central Turkey, a small assemblage of archaeobotanical remains and an insect were recovered from two specific archaeological contexts dated to the 540s B.C. This report documents a well-cleaned Triticum durum/aestivum grain cache retrieved from a baking area, along with hand-picked remains of Cornus mas, Cerasus cf. avium, and a Brachycerus sp. weevil.
\end{abstract}

Key Words: Kerkenes Dağ, Turkey, Phrygian, Iron Age, Archaeobotany, Archaeoentomology

\section{Introduction}

Kerkenes Dağ, located roughly $200 \mathrm{~km}$ east of Ankara, is a large Phrygian mountain-top city that lies on the northern edge of the Cappadocian plain in the Yozgat Province of modern-day Turkey (Figure 1). The walled single-period settlement, spanning roughly $2.5 \mathrm{~km}^{2}$, straddles a strategic location and has been tentatively identified as the ancient city of Pteria (Przeworski 1929). The occupation of the city spans the end of the 7th century B.C. and the mid-6th century B.C., placing it towards the very end of the Middle Phrygian period (which across the region dates between the $8^{\text {th }}$ century B.C. and the 540s B.C). The materials discussed here likely date to the last years prior to final destruction of the city by either Croesus or Cyrus in the 540s B.C. Survey work at the site began in 1993 under the direction of Geoffrey and Françoise Summers and has continued since then in collaboration with Scott Branting. Ongoing survey, intensive remote sensing, and excavation have yielded an impressive record documenting the occupation and urban architecture of the settlement (e.g., Branting 2004; Summers et al. 2011 and references cited therein).

\section{Archaeological Context of Samples}

During the 1996 season, test trenches were excavated at Kerkenes Dağ in order to: 1) better understand the nature of the architecture and the preservation of material across the site, and 2) compare this information with preliminary results of earlier remote sensing survey work (Summers and Summers 1996). As part of this effort, several trenches that had first been excavated in 1928 by Erich Schmidt were cleaned and, in some cases, extended beyond his original trench limits. Schmidt's Test Trench 5 (STT5), located close to the Gözbaba (Southwest) Gate was excavated, extending Schmidt's original "Site 5" into an urban block to the northwest (Schmidt 1929:237-240). This trench ended close to the edge of Schmidt's original "Site 4" located on the outside of the urban block wall (Schmidt 1929:234237). Site 4 was of particular interest because Schmidt's excavations had uncovered a large bakingoven and a secondary hearth. Both installations were found in place during the re-excavation of this area as STT4 in 1996 (Branting 2010:57). In close proximity to the oven, within the newly excavated portion of STT5, a stone paved surface covered in burnt grain and wood was exposed. The grain was likely being stored for later use in baking activities. A sediment sample measuring roughly 2 liters was collected by excavators from this surface for flotation.

Between 1999 and 2005, one main focus of excavation was on the eastern end of the city's largest compound, the Palatial Complex, located along the 


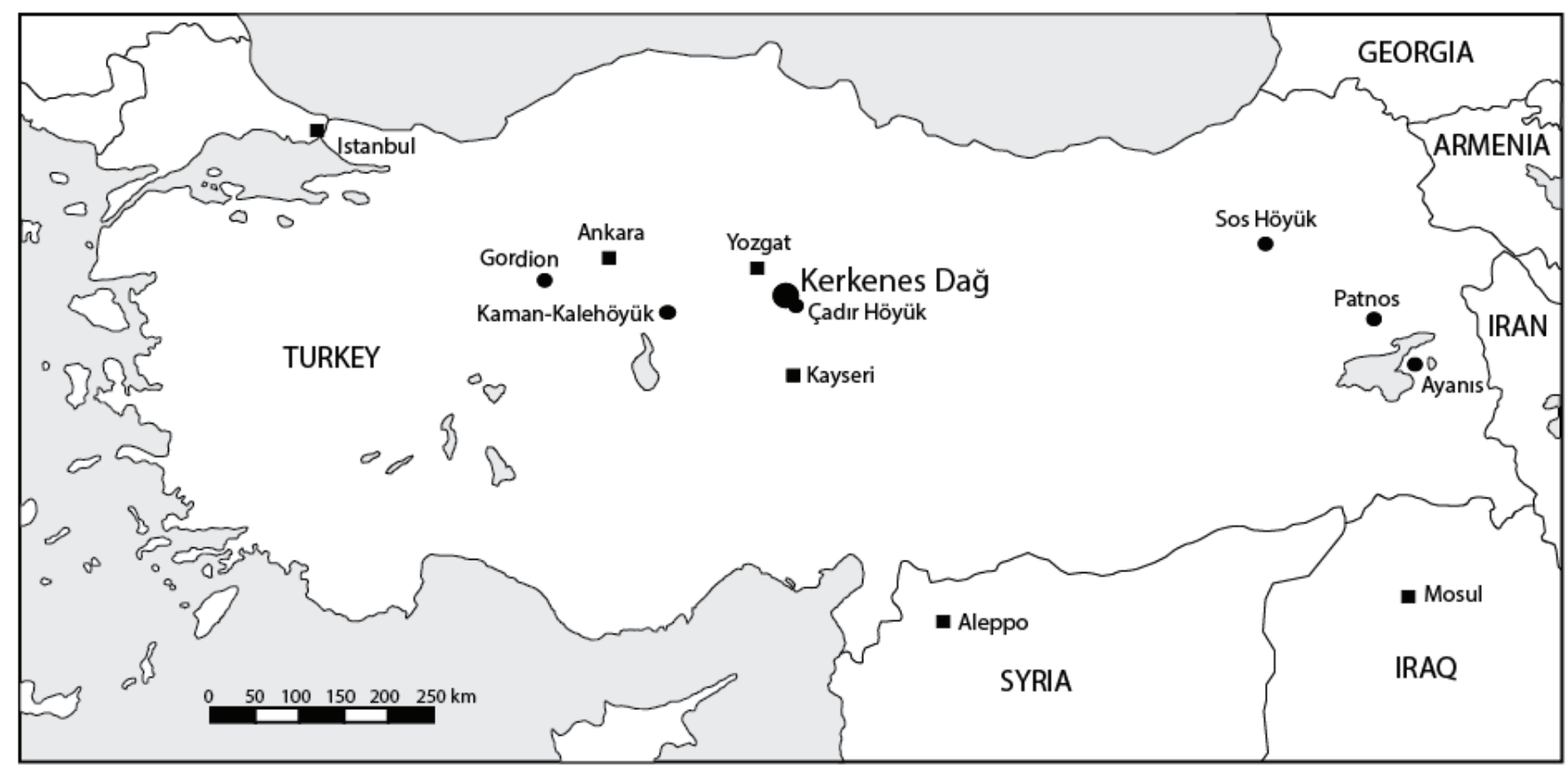

Figure 1. Location of Kerkenes Dağ and other Anatolian sites mentioned in text.

high southern ridge of the site. Three phases of rebuilding within the Palatial Complex were identified: the foundation dates to the second half of the 7 th century B.C. and the last phase of construction was completed just prior to the destruction of the city in the 540s B.C. (Draycott et al. 2008:4-5). During the 2000 season, excavations exposed a sloping stone glacis that formed the eastern edge of the Palatial Complex. Behind this wall, a number of structures were observed (Summers et al. 2000b:11-13). Structure C, a two-roomed stone building, was partially excavated revealing a small assemblage of complete pottery vessels (including a small twohandled pithos, a large conical bowl, two large flat lids, and a fine juglet) and bone inlay that may have been set into a small wooden container within destruction debris (Summers et al. 2001:11; Summers et al. 2000b:11-13). The function of these rooms remains unclear, but it is highly unlikely that they were used for domestic purposes. Seven sediment samples were collected for flotation from undisturbed burnt destruction debris lying atop the deeply buried floors of these rooms. Additionally, a single insect and a variety of clearly visible plant remains were handpicked from the surface of the floors by excavators.

\section{Methods}

Archaeobotanical remains were recovered from the seven sediment samples collected within the Palatial Complex during the 2000 season via bucket flotation by excavators. A 500-micron mesh was used to recover the light fractions. All light fractions were later visually scanned in the field by the lead author. Owing to the nature of bucket flotation, heavy fractions were not examined. Of the seven light fraction samples recovered, three yielded dense concentrations of wood charcoal and were sent to Reinder Neef (Deutsches Archäologisches Institut in Berlin) for a thorough anthracological study. Preliminary anthracological results indicate that Pinus nigra J. F. Arnold (black pine) was commonly encountered and that Quercus sp. L. (oak) and Juniperus sp. L. (juniper) were used to construct defensive architecture (Dörfler et al. 2000; Summers et al. 2000a). The remaining four samples contained modern botanical contaminants intermixed with small wood charcoal fragments and very few charred seeds. Since the number of seeds preserved was so low, these samples were not subjected to detailed analysis. The handpicked remains from this area are detailed below, however.

Archaeobotanical remains within the sample collected from the grain cache atop the stone floor in STT5 during the 1996 season were retrieved by the lead author using a modified Siraf flotation tank (the basic design of which is detailed in Nesbitt 1995). The 
light fraction was collected in a 250-micron mesh and dried in the shade. The heavy fraction was collected in a $2 \mathrm{~mm}$ mesh, dried and then examined in the field. No plant remains were recovered from the heavy fraction.

All archaeobotanical remains were identified by the lead author using the Archaeobotanical Comparative Collection at the University of Connecticut. Intact grains were counted as one. Large fragments were sorted into apical and embryo ends: the larger count of the two was used to estimate a whole seed count. Smaller cereal fragments were counted and converted to a whole seed count by dividing by four. The insect was identified by Robert Anderson of the Canadian Museum of Nature, Ottawa, and Rolf Oberprieler of CSIRO Entomology, Australia.

Owing to the opportunistic sampling strategy in place during the 1996 and 2000 seasons, the list of plant specimens reported here is undoubtedly incomplete, but the remains, nevertheless, provide information on Phrygian plant use at the site, a period for which agricultural production and wild resource collection is very poorly documented.

\section{Archaeobotanical Remains from STT5}

The dense assemblage of charred remains recovered from the stone floor in STT5, weighing 29.53g, contained virtually no modern contaminants, suggesting that the sample represents a localized, intact, intentionally placed deposit. This assertion is corroborated by micromorphological analyses conducted by Wendy Matthews, who examined thin-section samples from the oven area in STT4 and the stone paved area in STT5, and observed much greater disturbance and bioturbation in the former (Matthews 1996). The vast majority of the remains recovered from the stone floor were free-threshing Triticum durum/aestivum grains (Table 1, Figure 2A). Owing to significant morphological overlaps between T. durum and $T$. aestivum grains, is it not possible to distinguish between the two species based on observations of the grains alone. Rachis fragments, where present, can be used to distinguish between the two species (Zohary et al. 2012:32), but the grain cache had been well cleaned, and no rachis fragments were recovered. Measurements of 100 grains yielded a mean length, breadth, and thickness of 4.6, 3.1, and $2.4 \mathrm{~mm}$ respectively. These dimensions are similar to those found for $T$. durum/aestivum at other sites across Anatolia dating to the $1^{\text {st }}$ millennium B.C. (e.g., Dönmez 2003).
Free-threshing wheats were commonly cultivated across Anatolia during the first millennium B.C., as documented by remains from Gordion, Çadır Höyük, Patnos, Kaman-Kalehöyök and Sos Höyük, (Dönmez 2003; Fairbairn 2002; Longford et al. 2009; Marston 2012; Miller 2010; Smith 2007). The grain cache sample from Kerkenes Dağ yielded very small proportions of $T$. dicoccum and Hordeum vulgare ssp. distichum, both of which likely grew as incidentals amongst the T.durum/aestivum crop (Table 1). While occurring in only small proportions here, barley continued to be grown as a major crop in Anatolia during the $1^{\text {st }}$ millennium B.C., as evident from frequent Hordeum sp. finds within Phrygian levels at Gordion and fairly pure concentrations of $H$. vulgare ssp. distichum within the Iron Age fortress at Ayanıs (Marston 2012; Miller 2010; Peña-Chocorro et al. 2001).

Overall, very few weeds were present in the $T$. durum/aestivum cache, indicating that the crop was well cleaned. Since most of the weed seeds recovered approximated the size of a wheat grain, it would appear that the crop had been fully threshed and sieved and was awaiting further cleaning, via handpicking, before being ground into bread flour. Weeds within the assemblage include individual finds of Cephalaria syriaca, Carex sp., Bromus sp., Lolium sp., and Stipa sp., as well as three Galium/Asperula sp. seeds (Table 1). C. syriaca commonly occurs in fields and waste places as well as fallow fields and roadsides, and it is particularly abundant in hand sown wheat crops (Musselman 2000:541). Seeds produced by C. syriaca are similar in size to wheat grains, so it is necessary to handpick the contaminants from a crop in order to enhance the quality of the resultant grain. According to Hillman (1981:504), farmers often claim that "even five of the bitter seeds of Ziwan [C. syriaca] are enough to ruin a loaf of bread or bowl of bulgur," although he adds that this may be somewhat of an exaggeration. The other weeds present in the assemblage are mostly wild grasses and all are commonly reported as contaminants in cereal crops across Anatolia and elsewhere in Southwest Asia (The Archaeobotanical Database of Eastern Mediterranean and Near Eastern Sites, maintained by Simone Riehl and the University of Tuebingen Archaeology Dataset lists species encountered at many sites across Anatolia: http:// www.ademnes.de/). Since the weed seeds could not be identified beyond the genus level, no further comment on their potential relevance is possible. 
Table 1. Plant and insect remains recovered from Kerkenes Dag during the 1996 and 2000 field seasons.

\begin{tabular}{|c|c|c|c|c|c|c|}
\hline $\begin{array}{l}\text { Unit/ } \\
\text { Trench } \\
\text { (Season) }\end{array}$ & Taxon & Common Name & $\begin{array}{l}\text { Number Collected } \\
\text { (number of intact } \\
\text { specimens measured) }\end{array}$ & $\begin{array}{l}\text { Mean } \\
\text { length } \\
(\mathrm{mm})\end{array}$ & $\begin{array}{l}\text { Mean } \\
\text { width } \\
(\mathrm{mm})\end{array}$ & $\begin{array}{l}\text { Description of } \\
\text { context }\end{array}$ \\
\hline \multirow{14}{*}{$\begin{array}{l}\text { Unit 06, } \\
\text { STT5 } \\
(1996)\end{array}$} & $\begin{array}{l}\text { Triticum durum/ } \\
\text { aestivum }\end{array}$ & Durum/bread wheat & $575(100)$ & 4.6 & 3.1 & \multirow{14}{*}{$\begin{array}{l}\text { Carbonized } \\
\text { grain floor close } \\
\text { to baking oven. } \\
\text { Remains recov- } \\
\text { ered via flota- } \\
\text { tion from } 2 \text { li- } \\
\text { ters of sediment } \\
\text { (mass of } \\
\text { charred remains } \\
=29.53 \mathrm{~g} \text { ) }\end{array}$} \\
\hline & $\begin{array}{l}\text { Triticum dicoccum } \\
\text { Schübl. }\end{array}$ & Emmer wheat & 12 & - & - & \\
\hline & Triticum sp. L. & Wheat & 343 & - & - & \\
\hline & $\begin{array}{l}\text { Hordeum vulgare L. } \\
\text { ssp. distichum }\end{array}$ & $\begin{array}{l}\text { Two-row hulled bar- } \\
\text { ley }\end{array}$ & 3 & - & - & \\
\hline & Cereal indet. & Cereal & 80 & - & - & \\
\hline & Cephalaria syriaca (L.) & Syrian cephalaria & & - & - & \\
\hline & Schrader & & 1 & & & \\
\hline & Galium sp. L. & Bedstraw & 3 & - & - & \\
\hline & Carex sp. L. & Sedge & 1 & - & - & \\
\hline & Bromus sp. Scop. & Brome & 1 & - & - & \\
\hline & Lolium sp. L. & Rye grass & 1 & - & - & \\
\hline & Stipa sp. L. & Needle grass & 3 & - & - & \\
\hline & Indeterminate seeds & - & 3 & - & - & \\
\hline & Wood charcoal & - & $10 \mathrm{ml}$ & - & - & \\
\hline $\mathrm{PC}, * 03 /$ & Cornus mas (L.) & Cornelian cherry & $10(7)$ & 9.9 & 5.1 & Soil and rubble \\
\hline $\begin{array}{l}\text { CT 15N } \\
(2000)\end{array}$ & $\begin{array}{l}\text { Cerasus cf. avium (L.) } \\
\text { Moench }\end{array}$ & $\begin{array}{l}\text { Wild or sweet cher- } \\
\text { ry }\end{array}$ & 1 & 6.4 & 5.6 & Soil and rubble \\
\hline $\begin{array}{l}\text { PC, 03/CT } \\
15 \mathrm{~N} \\
(2000)\end{array}$ & Cornus mas & Cornelian cherry & $33(28)$ & 10.5 & 5.0 & $\begin{array}{l}\text { Hard soil in } \\
\text { southwestern } \\
\text { corner of CT15 } \\
\mathrm{N}, \text { rubble rear } \\
\text { sherds }\end{array}$ \\
\hline $\begin{array}{l}\mathrm{PC}, 05 / \mathrm{CT} \\
15 \mathrm{~N} \\
(2000) \\
\end{array}$ & Cornus mas & Cornelian cherry & $6(5)$ & 10.4 & 4.9 & $\begin{array}{l}\text { Burnt packed } \\
\text { soil }\end{array}$ \\
\hline $\begin{array}{l}\text { PC, 05/CT } \\
15 \mathrm{~N} \\
(2000) \\
\end{array}$ & Cornus mas & Cornelian cherry & $5(3)$ & 12.1 & 5.3 & Burnt layer \\
\hline $\begin{array}{l}\mathrm{PC}, 05 / \mathrm{CT} \\
18(2000)\end{array}$ & Brachycerus sp. Olivier & Garlic weevil & 1 & - & - & Floor of room 2 \\
\hline
\end{tabular}

*PC $=$ Palace Complex

Remains from the Palatial Complex

Unfortunately, very few seeds were recovered within the flotation samples collected from the floors of Structure $\mathrm{C}$ within the Palatial Complex. The handpicked charred plant remains, recovered from the surface of the floors within the northern room of Structure C (CT 15N), include Cornus mas endocarps and a single Cerasus cf. avium endocarp (Table 1;
Figure 2B and 2C).

Cornus mas L. (Cornelian cherry)

Within Turkey today, Cornus mas, commonly known as Cornelian cherry (Krzilicik in Turkish), is commonly cultivated as an ornamental shrub or small tree and is sometimes grown for its fruit (Davis 1972:541). Externally, C. mas stones resemble those of Olea 
A
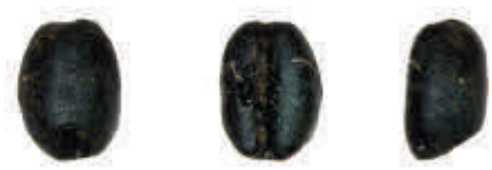

B

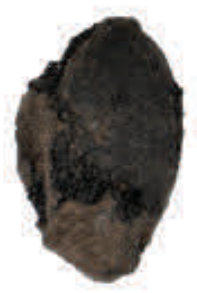

C
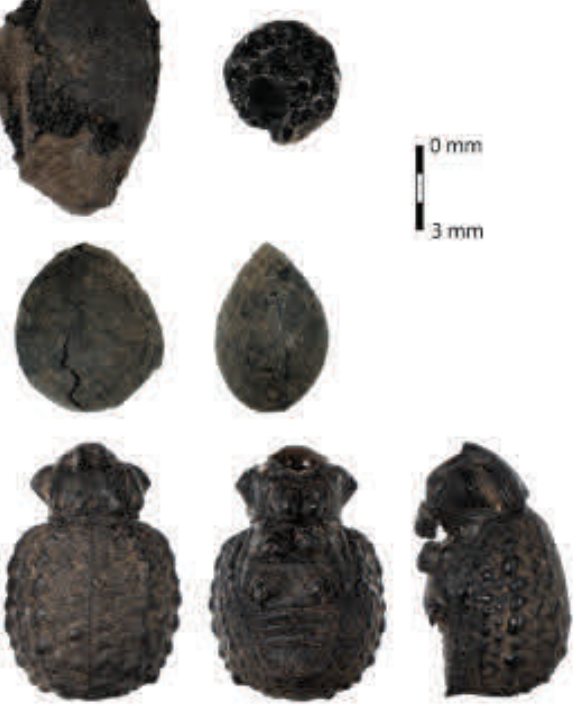

Figure 2. Photograph of: A) Triticum durum/aestivum grain in dorsal, ventral, and lateral view from left to right; B) two different Cornus mas endocarps in lateral and transverse view from left to right; C) Cerasus cf. avium endocarp in lateral, ventral, and apex view from left to right; D) Brachycerus sp. weevil in dorsal, ventral, and lateral view from left to right.

europaea L. (olive) although the outer endocarp or stone of C. mas tends to be much smoother than that of olive. When broken, the two species are readily distinguishable from one another since in transverse view, O. europaea stones contain a single seed cavity, whereas C. mas stones possess two (Figure 2B). In total, 54 C. mas endocarps were recovered, 43 of which were intact (Table 1). All intact endocarps were measured and varied in length from $7.4 \mathrm{~mm}$ to 13.1 $\mathrm{mm}$, with a mean and standard deviation of $10.5 \mathrm{~mm}$ and $1.3 \mathrm{~mm}$ respectively. Widths ranged between 3.8 $\mathrm{mm}$ and $6.2 \mathrm{~mm}$ with a mean and standard deviation of 5.0 and $0.5 \mathrm{~mm}$ respectively. Fragments of the fleshy mesocarp were still adhering to some of the stones recovered from Kerkenes Dağ (Figure 2B).

Cornus mas fruit is described by Sturtevant as harsh, acidic, and barely palatable, but despite his displeasure with the fruit, it still continues to be widely enjoyed across Europe and Southwest Asia where it is consumed raw or processed into jams, sweetmeats, and drinks (Dogan et al. 2004:686; Hedrick 1919:192-193). While C. mas remains are not routinely encountered on archaeological sites, its occurrence is certainly not rare and finds have been reported from a number of sites across Southwest Asia and Europe. Within Turkey today, wild forms of the plant are found mostly in northern and southern Turkey (Davis 1972:541). If the current distribution is similar to that evident during Iron Age, then it is possible that long distance exchange of $C$. mas existed across Anatolia, at least during the Iron Age. Gordon Hillman identified C. mas endocarps from Phrygian Megaron 3 at Gordion, where he describes the fruit as an import with "the probable nearest point of origin the Pontic mountain range" (DeVries 1990:383). Recent finds of C. mas wood in trash deposits at Gordion (Marston 2010:251) may argue against longdistance trade there, however, since the existence of wood within a trash context (as opposed to a curated context) could suggest that the plant was readily available locally. Since Kerkenes Dağ lies much closer to the northern range, it is likely that Cornelian cherries discussed here were obtained with relative ease.

\section{Cerasus cf. avium (wild or sweet cherry)}

A single Cerasus sp. endocarp resembling Cerasus cf. avium (synonymous with Prunus cerasus $\mathrm{L}$. var. avium) was recovered from the northern room of Structure C (03/CT 15N). C. avium trees occur across central and southern Europe, Caucasia, and northwestern Iran (Davis 1972:18), but may be native to North Turkey where they are referred to as "Kiraz." Davis (1972:18) notes, however, that today it can be difficult to distinguish between truly wild and naturalized populations. Modern-day drupes are ovoid, 6-12 $\times 4$ $10 \mathrm{~mm}$, containing a smooth stone surrounded by bitter flesh (Davis 1972:19). The endocarp from Kerkenes Dağ measures $6.4 \times 5.6 \times 4.4 \mathrm{~mm}$ and is entirely smooth, broadly elliptic in cross section, pointed at the apex, with only a slightly protruding ventral ridge that can be seen extending in lateral view (Figure 2C). Cerasus species are infrequently reported from archaeological sites across Southwest Asia, although they tend to be reported more frequently across Europe. Since little archaeobotanical work has been done in north-central Anatolia, it is unclear how widely this species was used across the region in 
antiquity.

\section{Brachycerus sp. (weevil)}

During recovery efforts within the southern room of Structure C (Room 2, Unit 5, Trench CT 18), a carbonized Brachycerus sp. weevil (a member of the Brachyceridae family, more commonly known as the garlic weevil), was recovered from an intact floor alongside a series of pottery vessels (Figure 2D). The preserved portion of the beetle measures $9.9 \mathrm{~mm}$ long, $6.9 \mathrm{~mm}$ wide, and $5.6 \mathrm{~mm}$ deep. Owing to the lack of legs and a head, it was not possible to identify the beetle to the species level, although Oberprieler (personal communication 2003) states that the specimen seems to "belong to the B. junix group." The charred beetle has every appearance of being ancient and was recovered from a secure context, but since members of the Brachycerus genus are known to burrow, and post-depositional disturbance in this area is evident, there is a slight possibility that it is intrusive.

Over the past decade, a number of archaeoentomology studies have highlighted the presence of ancient insects on archaeological sites allowing for discussion of post-harvest infestations of stored crops as well as climate change where the insects recovered have narrow ecological tolerances (e.g., Kislev et al. 2004). In this instance the weevil was found in close proximity to a series of ceramic storage vessels. Oberprieler (personal communication 2003) notes that Brachycerus sp. larva feed on live Liliaceae bulbs (sensu lato) in the ground. Unfortunately, no bulb remains were preserved or recovered within these rooms to shed further light on the contents of the vessels or the origin of the weevil.

\section{Conclusions}

During the 1996 and 2000 seasons at Kerkenes Dağ, a small assemblage of archaeobotanical remains was recovered. Hand-picked specimens retrieved from rooms of Structure $\mathrm{C}$ within the Palatial Complex include concentrations of Cornus mas endocarps, a Cerasus cf. avium endocarp, and a Bracbycerus sp. weevil. Exceptionally well-preserved Triticum durum/aestivum grains were recovered from a floor in STT5 in close proximity to a large baking installation. The cached crop contained small amounts of Triticum dicoccum and Hordeum vulgare, both of which likely were unintentionally grown along with the crop, as well as small amounts of Cephalaria syriaca, Asperula/Galium, and a range of wild grasses. The crop had been very well cleaned and was ready for hand-picking to remove wheat-sized contaminants before being ground into bread flour.

While the assemblage discussed here is small, and was not collected via a formal archaeobotanical sampling strategy, the remains provide information on Phrygian plant use in Anatolia, a time period for which agriculture and plant use is poorly understood. The remains also underscore the potential for future archaeobotanical studies at Kerkenes Dağ. Plant remains encountered on most sites across Southwest Asia become preserved via charring and since Kerkenes was destroyed by fire, the potential for excellent preservation of plant remains across the site is enormous, which provides a rare opportunity to examine spatial differences in plant use at a large, socially hierarchical, single occupation site. Continued work at the site will undoubtedly yield very exciting results.

\section{Acknowledgments}

We thank Geoffrey Summers and Françoise Summers for providing these samples and information on the archaeology of Kerkenes Dağ. We are immensely grateful to Bruce Archibald (Department of Biological Sciences, Simon Fraser University), Robert Anderson (Canadian Museum of Nature, Ottawa), and Rolf Oberprieler (CSIRO Entomology, Australia), for their assistance in identifying the weevil. Rolf Oberprieler generously provided a wealth of information regarding the life history of Brachycerus sp. We are also grateful to Geoffrey Summers and John M. Marston, as well as two anonymous reviewers, for providing thoughtful and very helpful comments on earlier drafts of this paper.

\section{References}

Branting, S. 2004. Iron Age Pedestrians at Kerkenes Dağ: an Archaeological GIS-T approach to movement and transportation. Unpublished Ph.D. Dissertation, Department of Anthropology, University at Buffalo, The State University of New York.

Branting, S. 2010. Agents in Motion. In Agency and Identity in the Ancient Near East: New Paths Forward, edited by S. R. Steadman and J. C. Ross, pp. 47-59. Equinox, London.

Davis, P. H. 1972. Flora of Turkey and the East Aegean Islands. Vol. 4. Edinburgh University Press, Edinburgh. 
DeVries, K. 1990. The Gordion Excavation Seasons of 1969-1973 and Subsequent Research. American Journal of Archaeology 94:371-406.

Dogan, Y., S. Baslar, G. Ay, and H. H. Mert. 2004. The Use of Wild Edible Plants in Western and Central Anatolia (Turkey). Economic Botany 58:684690.

Dönmez, E. O. 2003. Urartian crop plant remains from Patnos (A ğr1), eastern Turkey. Anatolian Studies 53:89-95.

Dörfler, W., R. Neef, and R. Pasternak. 2000. Untersuchungen zur Umweltgeschichte und Agrarökonomie im Einzugsbereich hethitischer Städte. Mitteilungen der Deutschen Orientgesellschaft 132:367-380.

Draycott, C. M., G. D. Summers, and C. Brixh. 2008. Kerkenes Special Studies 1: Sculpture and Inscriptions from the Monumental Entrance to the Palatial Complex at Kerkenes Dag, Turkey. Oriental Institute Publications 135. The Oriental Institute of the University of Chicago, Chicago.

Fairbairn, A. 2002. Archaeobotany at KamanKalehöyök 2001. Anatolian Archaeological Studies 11:201-212.

Hedrick, U. P. Editor, 1919. Sturtevant's Notes on Edible Plants. Report of the New York. Agricultural Experiment Station for the Year 1919. II. J. B. Lyon Company, Albany.

Hillman, G. 1981. Cereal Remains from Tell Ilbol and Tell Qaramel. In The River Qoueiq, Northern Syria, and its Catchment Studies arising from the Tell Rifa'at Survey 1977-79. BAR International Series 98 (ii), edited by J. Matthers, pp. 503-507. B.A.R, Oxford.

Kislev, M. E., A. Hartmann, and E. Galili. 2004. Archaeobotanical and archaeoentomological evidence from a well at Atlit-Yam indicates colder, more humid climate on the Israeli coast during the PPNC period. Journal of Archaeological Science 31:1301-1310.

Longford, C., A. Drinnan, and A. Sagona. 2009. Archaeobotany of Sos Höyük, Northeast Turkey. In New Directions in Archaeological Science, edited by A. Fairbairn, S. O'Connor, and B. Marwick, pp. 121-136. ANU-E-Press, Canberra.

Marston, J. M. 2010. Evaluating Risk, Sustainability, and Decision Making in Agricultural and Land-Use Strategies at Ancient Gordion. Unpublished Ph.D. Dissertation, University of California, Los Angeles.

Marston, J. M. 2012. Agricultural Strategies and Political Economy in Ancient Anatolia. American Journal of Archaeology 116:377-403.

Matthews, W., 1996. Preliminary Report on the Micromorphology of Depositional Sequences at the First Millennium BC Urban Settlement at Kerkenes Dağ, Central Anatolia. Available at: http:// www.kerkenes.metu.edu.tr/kerk1/06excav/ micromor/96repwm/index.html. Accessed on 28 February 2014.

Miller, N. F. 2010. Botanical Aspects of Environment and Economy at Gordion, Turkey. University of Pennsylvania Press, Philadelphia.

Musselman, L. J. 2000. Zawan and Tares in the Bible. Economic Botany 54:537-542.

Nesbitt, M. 1995. Recovery of Archaeological Plant Remains at Kaman-Kalehöyük. Bulletin of the Middle Eastern Culture Center in Japan 8:115-130.

Peña-Chocorro, L., A. Rigamonti, L. Castelletti, and A. Maspero. 2001. Preliminary Report on the Plant Remains from Ayanıs. In Ayanis I. Ten Years Excavations at Rusabinili Eiduru-kai 1989-1998, edited by A. Çilingiroğlu and M. Salvini, pp. 391-396. Rome: CNR, Istituto per gli studi micenei ed egeoanatolici.

Przeworski, S. 1929. Die Lage von Pteria. Archive Orientálni 1:312-315.

Schmidt, E. F. 1929. Test Excavations in the City on Kerkenes Dagh. The American Journal of Semitic Languages and Literatures 45:221-274. http:// www.jstor.org/stable/529203

Smith, A. 2007. Plant Use at Çadır Höyük, Central Anatolia. Anatolica 33:169-184.

Summers, G., and F. Summers, eds. 1996. Kerkenes 1996 Preliminary Report. Available at: http:// www.kerkenes.metu.edu.tr/kerk1/11prelim/1996/ english/index.html. Accessed on 28 February 2014.

Summers, G., F. Summers, S. Branting, and D. Langis -Barsetti, eds. 2011. The Kerkenes Project. A Preliminary Report of the 2011 Season. Available at: http://kerkenes.metu.edu.tr/kerk2/17downlds/ reportPdf/11kerkrepeng.pdf. Accessed on 28 
February 2014.

Summers, G., F. Summers, and D. Stronach. 2001. Kerkenes News 4. Ankara: Metu Press. Available at: http://kerk1.metu.edu.tr/12propub/ kerknews/2001/index.html. Accessed 28 February 2014.

Summers, G., F. Summers, D. Stronach, and M. Özcan, eds. 2000a. Kerkenes 2000 Preliminary Report. Available at: http:// www.kerkenes.metu.edu.tr/kerk1/11prelim/2000/ english/00_contents.html. Accessed on 28 February 2014.

Summers, G., F. Summers, D. Stronach, and M. Özcan. 2000b. Kerkenes News 3. Ankara: Metu Press. Available at: http:// kerk1.metu.edu.tr/12propub/kerknews/2000/ index.html. Accessed on 28 February 2014.

Zohary, D., M. Hopf, and E. Weiss. 2012. Domestication of Plants in the Old World. The Origin and Spread of Domesticated Plants in South-west Asia, Europe, and the Mediterranean Basin. Oxford University Press, New York.

\section{Biosketches}

Alexia Smith is Assistant Professor of Anthropology at the University of Connecticut.

Scott Branting is Director of the Center for Ancient Middle Eastern Landscapes, University of Chicago and of the Kerkenes Project. 